\title{
ЕФЕКТИВНІСТЬ ВИКОРИСТАННЯ ПРЕПАРАТІВ НЕБІЛКОВОГО АЗОТУ ДЛЯ ПІДВИЩЕННЯ ПРОДУКТИВНОСТІ МОЛОЧНОЇ ХУДОБИ
}

\author{
Супрун Ірина Олександрівна \\ кандидат сільськогосподарських наук, доцент \\ Національний університет біоресурсів і природокористування України \\ ORCID: https://orcid.org/0000-0001-8105-1923 \\ E-mail: isuprun@nubip.edu.ua
}

Куриленко Юрій Федорович кандидат сільськогосподарських наук, технічний консультант ТОВ «Біохем України» ORCID: https://orcid.org/0000-0002-4679-0242 email: yura236@ukr.net

Дослідження проведенні в аспекті використання джерела небілкового азоту для доповнення раціонів із кормами низької якості упродовж складних кліматичних та фізіологічних умов. Метою даних досліджень було підтвердження ефективності використання препарату небілкового азоту NitroShure для підвищення продуктивності великої рогатої худоби молочного напряму продуктивності та здешевлення собівартості продукції. Для встановлення ефрективності використання преnapamy NitroShure було проведено дослідження на базі СТОВ «Мусіївське» Полтавської обл., продуктивне стадо молочної худоби якого налічує 500 корів голштинської породи із середньою молочною продуктивністю 8000 кг молока на голову в рік. Технологія NitroShure дозволяє контролювати вивільнення азоту в рубці, що додатково дає можливість синхронізувати одночасне постачання мікроорганізмів рубия джерелами азоту і вуглеводів. Преnapam NitroShure виробництва компанії Балхем є одним із доступних на ринку джерел немікробного азоту в раціонах корів: в добавиі міститься 41\% азоту і 255\% сирого протеїну. До складу раціону 250 корів було введено преnapam NitroShure з розрахунку 100 грамів на голову, що дозволило скоротити кількість соняшникового шроту на 1,2 к己 (СП=39\%) та додати 1 кг кукурудзяного силосу з метою підвищення рівня крохмалю до $23 \%$ в раціонах тварин. Через місяць експерименту молочна продуктивність підвищилась в середньому на 2 л на голову на добу, вміст жиру становив 3,8\%, вміст білка - 3,15\%. Ретельний аналіз структури гною виявив значне зменшення кількості довгих волокон і грубих частинок, що опосередковано свідчить про підвищення ефективності перетравлення клітковини раціону, що і стало в результаті причиною підвищення молочної продуктивності. Завдяки перерахунку раціону економія його вартості на голову на добу із використанням NitroShure становила 5,15 грн, що в перерахунку на поголів'я на місяць склало 38625 грн. Прибуток від реалізації додатково отриманої кількості молока склав 180000 грн за місяць. Таким чином, IOFC склав 218625 грн за період використання преnapamy NitroShure у експериментальній групі. Поліпшення засвоєння азоту мікроорганізмами рубия дозволяє знизити рівень протеїну в раціоні. Препарат підвищує розщеплення вуглеводів в летючі жирні кислоти, що дозволяє знизити частку енергетичних добавок в раціоні. Застосування препарату забезпечує підвищення рівня надоїв за рахунок збагачення кормів різними джерелами енергії. Додаткове насичення кормів енергією збільшує виробництво молока і покращує його якісні показники, що створює можливість отримання додаткового прибутку (IOFC). IOFC

Ключові слова: жуйні, небілковий азот, сечовина, мікробіальний протеїн, NitroShure, молочна продуктивність,

DOI: https://doi.org/10.32845/bsnau.Ivst.2021.4.26

Відомо, що основною відмінністю між жуйними і не жуйними тваринами є різниця в системі їх травлення. Тоді як не жуйні тварини здатні перетравлювати лише справжні білки і використовувати їх для своєї життєдіяльності, жуйні можуть використовувати всі сполуки азоту [6]. Бактерії рубця жуйних, які відповідають за перетравлення клітковини відрізняє специфічна потреба в постійному добовому рівні аміаку (10-15 мг на добу) необхідному для задоволення потреб мікроорганізмів в енергії, яка затрачається на перетравлення клітковини та синтез мікробіалього протеїну. Ефективність роботи мікроорганізмів визначається його кількістю виробленою співвідносно до кількості ферментованої сухої речовини. Іншими словами, чим більше азоту отримають мікроорганізми рубця тварини, тим більш ефективно азот раціону буде перетворюватися в продукцію. Однак за умови стандартного раціону великої рогатої худоби, спостерігається нерівномірне надходження азоту в рубець та відповідно дисбаланс аміаку в рубці. Найчастіше в перервах між году- ванням жуйних, вміст аміаку в рубці стає занадто низьким, що порушує життєдіяльність бактерій [7]

Жуйні тварини здатні використовувати різні джерела білка через фізіологію свого шлунку. Мікроорганізми рубця синтезують білок з речовин, що містять азот для побудови своїх клітин. Жуйні використовують цей аспект мікроорганізмів для задоволення частини, а іноді і всіх своїх потреб в протеїні з небілкових сполук азоту (NPN) [4]. Тварини з простим шлунком (свині та кури) не можуть використовувати великі концентрації небілкових сполук азоту (NPN) через відсутність ферментів та бактерій для їх розщеплення до аміаку з подальшим його синтезом його у білок. Небілковий азот (або NPN) - це термін, який використовується у харчуванні тварин для загального позначення таких компонентів, як сечовина, біуретова сечова кислота та ряду інших сполук аміаку, які не $є$ білками, але можуть бути перетворені на білки мікробами в шлунку жуйних тварин [5]. NPN також можна визначити як азотовмісні складові раціону, які не 
пов'язані між собою пептидними зв'язками і знаходяться всередині або поза системою організму тварини. Усі NPN генерують аміак у рубці, який надходить у печінку і, нарешті, перетворюється на сечовину.

Небілкові сполуки азоту містяться в багатьох кормах. Наприклад, 20-30\% всього азоту наявно в траві на пасовищі, 50\% - в силосі, 40-50\% цільного азоту міститься в коренеплодах, а його вміст зменшується у міру дозрівання рослин [11]. Серед проблем, з якими стикається тваринництво в посушливих регіонах - це травостій з низьким вмістом білка поруч із високою вартістю альтернативних джерел білка, таких як соєвий шрот та макуха. Бобові корми, багаті білком, не вирощуються в багатьох районах, де випасають жуйних тварин, і рослинні білкові добавки зазвичай є дорогими або недоступними. Згодовування трави та концентратів з низькою харчовою цінністю не завжди задовольняє харчові потреби жуйних тварин, тому їх слід замінити відповідними альтернативами в кормі. В таких умовах одним з таких альтернативних джерел протеїну стає використання сполук небілкового азоту (NPN). Частка азоту в кормах для жуйних тварин можуть бути представлені у формі небілкових сполук азоту, які розкладаються в рубці із виділенням аміаку (NH3), який використовується мікроорганізмами рубця для виробництва амінокислот [9]. Вже давно визнано, що додатковий небілковий азот (NPN) використовується найбільш ефективно в раціонах з низьким вмістом білка і відносно високим вмістом перетравної енергії. Також широко відомо, що добавки NPN краще використовується, коли до раціонів жуйних додають їх невеликі кількості [14].

Основним комерційним джерелом NPN для використання в раціонах жуйних тварин є сечовина - NPN це проста сполука, яка містить 46,7\% азоту проти 16 \% більшості білків. Таким чином кожен кілограм сечовини еквівалентний 2,88 кг сирого протеїну, що у більшості раціонів дорівнює вмісту перетравного сирого протеїну на 200\%. Про те, що використовувати сечовину як білкову добавку в раціонах жуйних тварин економічно вигідніше натомість високовартісного соєвого шроту було відомо вже давно [15].

Проте, хоч сечовина і зупиняє ріст та ферментацію бактерій концентрацією понад 10\%, але надає гіркуватого присмаку корму і обмежує його споживання при високому її вмісті.

Після потрапляння сечовини з джерелами корму до рубця, вона швидко розчиняється і гідролізується в аміак завдяки бактеріальній уреазі. Потім аміак може бути використаний бактеріями для синтезу необхідних для життєдіяльності організму амінокислот [12]. Важливе значення відіграє застосування сечовини в регіонах із розвинутим скотарством, як правило, під час періодично складних кліматичних умов [8].

На сьогодні оприлюднено значну кількість результатів експериментів із використання небілкового азоту в раціоні жуйних. Так, Ryley J.W. [13] виявив, що при невеликому додаванні сорго та сечовини до раціону спостерігається покращення живої маси новонароджених телят, зниження неонатальної смертності, спостерігається підвищення надоїв та швидкості росту телят. Bames R.M. [1] також свідчить про ефективність використання сечовини в раціоні під час посухи. Ще раніше дослідження Briggs P.K. [3] показали, що ягнята можуть збільшувати прирости живої маси за використання раціонів, що містять від 40 до 65 відсотків азоту у ви- гляді сечовини. Здатність присутніх у рубці мікроорганізмів жуйних тварин до використання кормової сечовини дозволяє зменшити потребу в імпортних білкових добавках з відсутністю негативного впливу на тварину. Кількість сечовини, що входить до складу сумішей концентратів для великої рогатої худоби чи овець, не повинна перевищувати 3 \% і зазвичай додавання від 1 до 1,5 \% є достатнім [8].

Поруч із цим $\epsilon$ непоодинокі свідчення про токсичність сечовини за умови надмірного споживанням кормів, що містять сечовину, або згодовування сечовини без забезпечення бродіння завдяки достатній кількості вуглеводів.

Токсичність сечовини пов'язана в першу чергу з тим, що незахищена сечовина швидко вивільняється в рубці і мікроорганізми не встигають засвоювати азот. Незасвоєний азот в рубці підвищує вміст аміаку, що призводить до інтоксикації організму жуйних. Лише незначна кількість незахищеної сечовини ефективно використовується в годівлі дійних корів [10]. Серед причин отруєння сечовиною називають також нерівномірне змішування кормів, помилки у складанні раціону, недостатній період адаптації до раціону із введенням сечовини, низький рівень споживання води, згодовування сечовини разом із неякісними кормами, споживання корму із сечовиною натще, і раціони, які сприяють створенню високому рН в рубці [16].

Незважаючи на вказані недоліки використання, джерела небілкового азоту залишаються перспективними для доповнення раціонів із кормами низької якості протягом складних кліматичних та фізіологічних умов: посушливого сезону, коли корови піддаються кормовому стресу під час вагітності або лактації, що може серйозно погіршити їх продуктивність протягом усього життя.

Метою даних досліджень було підтвердження ефективності використання препарату небілкового азоту для підвищення продуктивності великої рогатої худоби молочного напряму продуктивності та здешевлення собівартості продукції.

Матеріали та методи досліджень. Для встановлення есрективності використання препарату NitroShure, ми провели дослідження на базі СТОВ «Мусіївське», Полтавської обл. Продуктивне стадо господарства налічує 500 корів голштинської породи із середньою молочною продуктивністю 8000 кг молока на голову в рік. Протягом періоду згодовування препарату NitroShure проводився регулярний моніторинг кількісних та якісних показників молочної продуктивності шляхом щодекадних контрольних доїнь та моніторинг перетравності клітковини раціону шляхом дослідження консистенції і структури гною з використанням спеціального набору сит для сепарації (NASCO, США).

Результати досліджень. На сьогодні існує безліч кормових добавок, які здатні поліпшувати ферментацію рубця і життєздатність мікробів. Одним із напрямків $є$ додавання небілкового азоту до раціонів жуйних. Серед них препарат NitroShure, який дозволяє контролювати вивільнення азоту в рубці, що додатково дає можливість синхронізувати одночасне постачання мікроорганізмів рубця джерелами азоту і вуглеводів. Швидкість вивільнення азоту і рівень ферментації вуглеводів широко варіює. Залежно від джерела, мікробіальний білок багатий незамінними амінокислотами (лізином та метіоніном). Оптимізація процесу бродіння в рубці покращує постачання організму тварин амінокислотами, що $€$ важливим чинником для збільшення показників 
продуктивності.

Для оптимізації процесу ферментації азот вивільняється і координує ферментацію вуглеводів. 3 метою підвищення ефективності даного процесу використовують захищену сечовину, подібну за процесами бродіння з ферментацією меленої кукурудзи. Заміна джерел білка (наприклад, соєвого шроту) препаратом NitroShure звільняє напруженість раціону, що дозволяє включати більшу кількість кормів із вмістом клітковини як джерела енергії. Якщо раціон має низький енергетичний склад, то введення в раціон NitroShure створює можливість засвоювати максимальну кількість енергії з компонентів корму. Раціон з низьким вмістом протеїну (<16\% СП) часто $€$ причиною низького рівня виробництва молока. У таких випадках додавання в раціон 80 г NitroShure підвищує вміст білка у всіх раціонах з 16 до 17\% СП (сирого протеїну). Процес бродіння в рубці стає більш ефективним, і виробництво молока збільшується, а також поліпшуються його якісні показники.

Препарат NitroShure виробництва компанії Балхем $€$ один із доступних на ринку джерел немікробного азоту в раціонах корів: в добавці міститься $41 \%$ азоту і $255 \%$ сирого протеїну. За даними виробника, використання препарату дозволяє знизити витрати за еквівалентом сирого протеїну: 150г Nitro Shure $=846$ г соєвого шроту; 150г NitroShure = 1140 г рапсового шроту.

При цьому, згідно з результатами досліджень, 6,3\% небілкового азоту стають доступними відразу ж після споживання, в той час як швидкість його подальшого засвоєння становить 8\% на годину. Експериментальним шляхом було встановлено, що при додаванні небілкового азоту в ферментери чисельність рубцевих бактерій збільшувалася на $5 \%$. Поліпшення життєздатності i фрункцій мікрофрлори рубця сприяє підвищенню надоїв в середньому на 1,8 кг молока на голову на добу [7]. Окрім вдосконалення складу раціону, додавання джерела небілкового азоту дозволяє збалансувати вихід азоту і забезпечити постійний оптимальний його рівень. Контрольоване і безперебійне постачання азоту сприяє зростанню синтезу «справжнього» протеїну для виробництва молока - мікробіального протеїну на 10- 20\%. Окрім цього, використання добавки дозволяє скоротити кількість загального азоту в раціоні, оскільки він використовується в організмі більш ефективно і з меншими втратами. Додавання небілкового азоту сприяє перетворенню азоту кормів в бактеріальний азот.

В грудні 2020 р до складу раціону 250 корів голштинської породи було введено препарат NitroShure з розрахунку 100 грамів на голову на добу, що дозволило скоротити кількість соняшникового шроту на 1,2 кг (СП=39\%) і додати 1 кг кукурудзяного силосу з метою підвищення рівня крохмалю до 23\% (табл.1) в раціонах тварин.

Раціон дійної корови на період використання добавки

Таблиця 1

\begin{tabular}{|c|c|c|c|}
\hline Компонент & Кількість в СР, кг & Вартість 1 кг компонента раціону, грн & Загальна вартість, грн \\
\hline Кукурудзяний силос, кг & $8,16(7,16)^{*}$ & 3,00 & $24,48(21,48)^{*}$ \\
\hline Силос із тритікале, кг & 3,51 & 8,00 & 28,08 \\
\hline Сінаж люцерновий, кг & 1,62 & 6,00 & 9,72 \\
\hline Кукурудза (зерно), кг & 4,60 & 8,00 & 36,80 \\
\hline Соєвий шрот, кг & 2,14 & 18,0 & 38,52 \\
\hline Ячмінь, кг & 0,90 & 7,00 & 6,30 \\
\hline Меляса, кг & 1,17 & 5,00 & 5,85 \\
\hline Сіно, кГ & 1,20 & 3,00 & 3,60 \\
\hline Соняшниковий шрот, кг & $0,74(1,94)^{*}$ & 11,50 & $8,16(22,31)^{*}$ \\
\hline Премікс, кг & 0,14 & 30,00 & 4,20 \\
\hline Сіль, кг & 0,15 & 3,00 & 0,45 \\
\hline Сода & 0,15 & 12,00 & 1,80 \\
\hline NitroShure & 0,10 & 81,00 & 8,10 \\
\hline Всього & - & - & $176,06(181,21)$ \\
\hline
\end{tabular}

В результаті використання джерела небілкового азоту молочна продуктивність в стаді через тиждень підвищилась на 1 л на голову на добу. Так на початок періоду використання препарату NitroShure вона складала 26,5 л на голову на добу, через 7 днів використання препарату підвищилась до 27,5 літрів молока на голову на добу. Якісні показники молочної продуктивності (вміст жиру та білка) не змінилися: $3,8 \%$ та $3,17 \%$.

Через місяць експерименту показники молочної продуктивність були наступними: надій 29 л на голову на добу вміст жиру $3,8 \%$, вміст білка 3,15\%. Загалом підвищення молочної продуктивності для 250 голів становило 700 л на добу. Таким чином підвищення кількості молока в середньому на голову на добу склало 2 л.

Аналіз структури гною виявив значне зменшення кількості довгих волокон і грубих частинок, що опосередкова- но свідчить про підвищення ефективності перетравлення клітковини раціону, що і стало в результаті причиною підвищення молочної продуктивності.

Завдяки перерахунку раціону економія корму за місяць склала 9000 кг соняшникового шроту за ціною 11,5 грн/кг, що загалом становить 103500 грн. Витрати на згодовування добавки NitroShure за ціною 81 грн/кг в дозуванні 0,1 кг на голову становили 750 кг по 81 грн, що загалом здорожчало раціон на 60750 грн. Додатковими також були витрати на кукурудзяний силос загальною вартістю на на місяць у 22500 грн. Загальна вартість раціону на голову на добу із використанням NitroShure зменшилася на 5,15 грн, що в перерахунку на поголів'я на місяць склало 38625 грн. Прибуток від реалізації додатково отриманої кількості молока склав 180000 грн за місяць (табл. 2). 
Таблиця 2

Розрахунок економічної ефективності від використання препарату NitroShure

\begin{tabular}{|c|c|c|c|c|}
\hline Кількість тварин за період & $\begin{array}{c}\text { Вартість раціону без } \\
\text { використання препарату, грн }\end{array}$ & $\begin{array}{c}\text { Вартість раціону з } \\
\text { використанням препарату, грн }\end{array}$ & $\begin{array}{c}\text { Прибуток від додатково } \\
\text { отриманої кількості молока, грн }\end{array}$ & IOFC $^{*}$, грн \\
\hline На голову на добу & 181,21 & 176,06 & 24 & 29,15 \\
\hline На голову на період & 5436,30 & 5281,8 & 720 & 874,5 \\
\hline На всю групу на добу & 45302,50 & 44015,0 & 6000 & 7287,5 \\
\hline На всю групу на період & 1359075 & 1320450 & 180000 & 218625 \\
\hline
\end{tabular}

*IOFC - (income over feed cost ) прибуток понад витратами на годівлю

Для підтвердження економічної ефективності від використання препарату ми розрахували IOFC (income over feed cost) - прибуток понад витратами на годівлю, який вимірюється в гривнях на одну лактуючу корову на добу. Для розрахунку ми використали модифіковану методику Beck T., Ishler Virginia A. [2]: IOFC (грн/корова/доба) = Pmilk x DAMP DFC, дe

Pmilk - це валова вартість молока (грн), DAMP - це середньодобовий надій (л/корову/день), а DFC - це середньодобові витрати корму грн/корову/добу). DFC - це щоденна вартість кормів, необхідних для виробництва кількості молока, відображеного в DAMP.

Фактично цей індекс показує різницю між прибутком від реалізації молока від однієї корови та витратами на її годівлю.

За нашими даними IOFC на корову на добу з використання препарату складає: 12 грн х 29 л - 176,06=171,94 грн, а без використання IOFC (грн/корову/добу): 12 грн х 27 $л-181,21=142,79$ грн. Отримуємо суттєву різницю у 29,15 грн на голову на добу на користь групи із використанням препарату. Таким чином, IOFC становить 218625 грн за період використання препарату NitroShure у експериментальній групі.

Висновки. 1. Використання джерела небілкового азоту у вигляді препарату NitroShure дозволяє підтримувати постійне надходження мікробного протеїну в організмі молочної худоби навіть при дисбалансі білка в раціоні, що дозволяє фахівцям з годівлі модифікувати раціони жуйних з дода- ванням сухої речовини на вивільнені позиції.

2. Застосування альтернативного джерела небілкового азоту у вигляді препарату NitroShure дає можливість згодовувати в раціоні жуйних більше кормів, забезпечуючи при цьому максимальний рівень їх засвоєння.

3. Заміна низькоякісних білків продуктом NitroShure сприяє виробленню високоякісного мікробіального білка.

4. Рентабельність раціонів, що включають в себе NitroShure, досягається мінімальними витратами за рахунок можливості використання ширшого спектра кормових інгредієнтів.

5. Поліпшення засвоєння азоту мікроорганізмами рубця дозволяє знизити рівень протеїну в раціоні.

6. Препарат підвищує розщеплення вуглеводів в летючі жирні кислоти, що дозволяє знизити частку енергетичних добавок в раціоні.

7. Застосування препарату дозволяє збагатити корми підвищеним вмістом клітковини з дешевших джерел. При цьому збільшується кількість розщепленого протеїну в рубці, що в свою чергу забезпечує максимальне засвоєння клітковини.

8. Застосування препарату забезпечує підвищення рівня надоїв за рахунок збагачення кормів різними джерелами енергії. Додаткове насичення кормів енергією збільшує виробництво молока і покращує його якісні показники, що створює можливість отримання додаткового прибутку (IOFC).

\section{Список використаної літератури:}

1. Beames, R.M. 1963. Provision of urea to cattle in salt-urea-molasses block. Qld J. Agric. Sci., 20: 21 3-230.

2. Beck Tim, Ishler Virginia A. Managing Income Over Feed Costs (Online) https://extension.psu.edu/managing-incomeover-feed-costs

3. Briggs, P.K. 1960. Urea as a nitrogen supplement in the utilization of low-quality roughage by Merino sheep. Proc. 8th int. Grass. Congr., p. 579-583.

4. Currier T. A., Bohnert D. W., Falck S. J., Schauer C. S. and Bartle S. J., 2004. Daily and alternate-day supplementation of urea or biuret to ruminants consuming low-quality forage: II. Effects on site of digestion and microbial efficiency in steers, J. Anim. Sci. 2004. 82:1508-1517 http://dx.doi.org/10.2527/2004.8251508x

5. Datasheet Under Construction, 2010. Http://Www.Feedipedia.Org/Node/58

6. Huntington, G.B. 1986. Uptake and transport of nonprotein nitrogen by the ruminant gut. Fed. Proc. 45:2272-2276.

7. Huntington, G.B., Harmon, D.L., Kristensen, N.B., Hanson, K.C. \& Spears, J. W. 2006. Effects of a slow release urea source on absorption of ammonia and endogenous production of urea by cattle. Anim. Feed Sci. Technol. 130:225-241. https://doi.org/10.1016/j.anifeedsci.2006.01.012

8. Morris, J.G. 1958. Drought feeding studies with cattle and sheep. I. The use of native grass hay (bush hay) as the basal component of a drought fodder for cattle. Qld J. Agric. Sci., 15: 161-180.

9. Nadeem, M. S., Pasha, T. N., Jabbar, M. A , Javed, K., Khan, M. Z. Naveed S. and Ditta, Y. A., 2014. Effect of of Different Non-Protein Nitrogen (NPN) Sources on Performance of Lactating Nili-Ravi Buffaloes, The Journal of Animal \& Plant $\begin{array}{lllllll}\text { Sciences, } & \text { 24(Suppl. } & \text { 1): } & 2014, & \text { Page: } & 1-4 & \text { ISSN: }\end{array}$ https://citeseerx.ist.psu.edu/viewdoc/download?doi=10.1.1.1037.4143\&rep=rep1\&type=pdf

10. Ortolani, E. I., Mori, C. S., Filho, J. A. R. 2000. Ammonia toxicity from urea in a Brazilian dairy goat flock. Veter. and Human Toxico. 42(2): 87-89. https://pubmed.ncbi.nlm.nih.gov/10750172/

11. Ozgen, H., 1978. Animal Nutrition. Ankara University Printing House, Ankara, Turkey, pp: 60-61. 
12. Panday Dinesh, 2010. Urea as A Non-Protein Nitrogen Sources For Ruminants, Alltech Young Scientist Competition, https://fliphtml5.com/rzpg/eelq/basic

13. Ryley, J.W. 1961. Drought feeding studies with cattle. 6. Sorghum silage, with and without urea, as a drought fodder for cattle in late pregnancy and early lactation. Queensland Journal of Agricultural Science 1961 Vol.18 pp.409-424 https://www.cabdirect.org/cabdirect/abstract/19631401518

14. Satter, L.D. and, Roffler, R.R., 1977. Protein Requirement and Non Protein Nitrogen Utilization, Trop Anim Prod 1977 2:3 https://cipav.org.co/TAP/TAP/TAP23/2_3_1.pdf

15. Stanton, T.L. \& Whittier, J. 1998. Urea and NPN for Cattle and Sheep Colorado state university Extantion, Fact Sheet №1.608, Livestock Series|Management https://extension.colostate.edu/docs/pubs/livestk/01608.pdf

16. Tadele Yilkal, Amha Negassie, 2015, Use of Different Non Protein Nitrogen Sources in Ruminant Nutrition: A review Advances in Life Science and Technology www.iiste.org ISSN 2224-7181 (Paper) ISSN 2225-062X (Online) Vol.29, https://core.ac.uk/download/pdf/234687103.pdf

Suprun Irina Alexandrovna, Candidate of Agricultural Sciences, Associate Professor

Kurylenko Yuri Fedorovich, Candidate of Agricultural Sciences

(Kyiv, Ukraine)

Efficiency of using non-protein nitrogen preparations to increase the productivity of dairy livestock

Research is conducted in the aspect of using a source of non-protein nitrogen to supplement rations with low-quality feeds during difficult climatic and physiological conditions. The aim of these studies was to confirm the effectiveness of the use of nonprotein nitrogen NitroShure to increase the productivity of dairy cattle productivity and reduce the cost of production. To establish the effectiveness of the drug NitroShure, we conducted a study on the basis of agricultural farm "Musiivske", Poltava region. The productive herd of the farm has 500 Holstein cows with an average milk yield of 8,000 kg of milk per head per year. NitroShure technology allows you to control the release of nitrogen in the rumen, which further allows you to synchronize the simultaneous supply of rumen microorganisms with sources of nitrogen and carbohydrates. Balchem's NitroShure is one of the commercially available sources of non-microbial nitrogen in cows' diets: the supplement contains $41 \%$ nitrogen and $255 \%$ crude protein. NitroShure was added to the diet of 250 cows at the rate of 100 grams per head, which reduced the amount of sunflower meal (SP = $39 \%$ ) (by $1.2 \mathrm{~kg}$ ) and add $1 \mathrm{~kg}$ of corn silage to increase the starch level to $23 \%$ in the diets of animals. After a month of the experiment, the indicators of milk productivity milk productivity increased by an average of 2 liters per head for fat content was $3.8 \%$, protein content $-3.15 \%$. Careful analysis of the structure of manure revealed a significant reduction in the number of long fibers and coarse particles, which indirectly indicates an increase in the efficiency of digestion of dietary fiber, which resulted in increased milk productivity. Due to the recalculation of the ration, the cost savings per ration per day using NitroShure amounted to UAH 5.15, which in terms of livestock per month amounted to UAH 38,625. Profit from the sale of additional milk received amounted to UAH 180,000 per month. Thus, IOFC amounted to UAH 218,625 for the period of use of NitroShure in the experimental group. Therefore, it can be concluded that improving the absorption of nitrogen by the microorganisms of the rumen allows to reduce the level of protein in the diet. The drug increases the breakdown of carbohydrates into volatile fatty acids, which reduces the proportion of energy supplements in the diet. The use of the drug provides an increase in milk yield due to the enrichment of feed with various energy sources. Additional saturation of feed with energy increases milk production and improves its quality, which creates the possibility of additional income (IOFC).

Key words: ruminants, non-protein nitrogen, urea, microbial protein, NitroShure, milk productivity, IOFC

Дата надходження до редакції: 03.10.2021 р. 